\title{
Potential Bacterial Consortium to Increase the Effectiveness of Beer Wastewater Treatment
}

\author{
PUTU NIA ANGGRAENI' ${ }^{1}$ IDA BAGUS WAYAN GUNAM ${ }^{2}$ and RETNO KAWURI ${ }^{3}$
}

\author{
${ }^{1}$ Magister of Biology Science, Graduate School of Udayana University, Denpasar Bali, Indonesia. \\ ${ }^{2}$ Laboratory of Bioindustry and Environmental, Faculty of Agriculture Technology, \\ Udayana University, Bukit Jimbaran, Bali 80-361, Indonesia. \\ ${ }^{3}$ Laboratory of Microbiology Faculty of Mathematic and Natural Sciences, \\ Udayana University, Bukit Jimbaran, Bali 80-361, Indonesia.
}

http://dx.doi.org/10.12944/CWE.9.2.11

(Received: May 19, 2014; Accepted: June 20, 2014)

\begin{abstract}
The main objective of this research is to determine the effectiveness of microbial consortia in beer wastewater treatment. The research was initiated with the isolation of soil microbial consortium that has been contaminated by beer waste water, followed by the selection of the best potential microbial beer wastewater treatment. At the end, the selection of the best microbial consortium was tested in beer wastewater treatment based on pollutant parameters namely biochemical oxygen demand (BOD), chemical oxygen demand (COD) and total suspended solid (TSS). The most effective combination of microbial consortia to reduce the value of TSS, BOD, and COD is the mixed culture combination of Cronobacter sp. strain NGS4, Pseudomonas fluorescent NGS5, and Aeromonas sp. strain NGS7. After 12 days of treatment the value of the COD, BOD and TSS are $633,69 \pm 48,18$ with degradation rate $66,06 \% ; 199,09 \pm 87,82$ with degradation rate $78,91 \%$; and $848,9 \pm 206,61$ with degradation rate $90,50 \%$ respectively.
\end{abstract}

Key words: Beer wastewater, Degradation, Bacterial consortium, BOD, COD, TSS.

\section{INTRODUCTION}

Brewery industry wastewater contains organic waste with pollution levels depend on the beer production process and capacity of water consumption during the process (Olafadehan and Aribike, 2000; Driessen and Vereijken, 2003). One of the wastewater treatment system which is interesting to be developed is a biological treatment using microorganisms. Biological treatment system is suitable for handling beer wastewater containing dissolved and suspended organic matter. This system uses microbial activity to oxidize organic compounds with the aid of molecular $\mathrm{O}_{2}$ into $\mathrm{CO}_{2}$, water, and a new cell (Bitton, 2005; Nusanthary et al., 2012).
Degradation processes in the environment are generally carried out by a consortium of microbes rather than by one type of microbes alone (Thompson et al., 2005). Processing system that uses a mixed microbial cultures will provide results that are more effective than single cultures because of the catabolic activity of the bacterial culture complement each other and the resulting decomposition products of a culture can be used by other cultures for further decomposition process that can help to improve wastewater oxidation of organic matter (Jadhav et al., 2008). This study aims to get the best microbial consortium capable of treating wastewater and eventually beer wastewater discharged into the environment can be reused for the life processes. 


\section{MATERIALS AND METHODS}

\section{Sampling of beer wastewater}

Beer wastewater samples originated from PT. Storm Beer, Sukasada, Bali and performed by using the grab method (Kardono, 2008).

\section{Isolation of beer wastewater degrading bacteria}

The bacteria were isolated from soil contaminated by beer waste water by using platting method and liquid mineral medium consisting of: $1.0 \mathrm{~g}\left(\mathrm{NH}_{4}\right)_{2} \mathrm{SO}_{4} ; 1.0 \mathrm{~g} \mathrm{KH}_{2} \mathrm{PO}_{4} ; 3.6 \mathrm{~g} \mathrm{Na}_{2} \mathrm{HPO}_{4} ; 1.0$ $\mathrm{g} \mathrm{MgSO}_{4} .7 \mathrm{H}_{2} \mathrm{O} ; 0.01 \mathrm{~g} \mathrm{Fe}\left(\mathrm{NH}_{4}\right) \mathrm{S} ; 1.0 \mathrm{~g} \mathrm{CaCl}_{2} .2 \mathrm{H}_{2} \mathrm{O}$; and $0.5 \mathrm{~g}$ yeast extract (all per litre distilled water). The $\mathrm{pH}$ of the medium was adjusted to 7 before autoclaving at $121^{\circ} \mathrm{C}$ for 15 mins and were incubated at $37^{\circ} \mathrm{C}$ for 48 hours. Isolates were stored in $40 \%$ glycerol $(\mathrm{v} / \mathrm{v})$ at $-20^{\circ} \mathrm{C}$. Furthermore, inoculation of bacteria was using Nutrient Agar medium and then cultivated by using Nutrient Broth medium and incubated at $37^{\circ} \mathrm{C}$ for 48 hours (Khehra et al., 2006).

\section{Growth of Bacterial Cells}

Bacterial isolates obtained from the isolation and has been cultivated further centrifuged at 3500 rpm for $30 \mathrm{~min}$, then the cell pellet was washed and diluted with $0.8 \% \mathrm{NaCl}$ solution to a volume of $10 \mathrm{~mL}$. Growth in the number of bacterial cells was predicted by optical density using a spectrophotometer at a wavelength of $660 \mathrm{~nm}$ every 24 hours (Waluyo, 2004).

\section{Selection of bacterial isolates}

Selection of potential bacterial isolates was performed by pollutant parameters (COD, BOD and TSS) by measuring the turbidity of the early stages of bacterial inoculum culture (Optical Dencity, OD) using a spectrophotometer. Bacterial isolates obtained from the isolation and has been cultivated further centrifuged at $3500 \mathrm{rpm}$ for $30 \mathrm{~min}$ and washed with $0.8 \% \mathrm{NaCl}$ until clean, then the OD was adjusted to OD5 by diluting $10 \mathrm{~mL}$ cell suspension with $0,8 \% \mathrm{NaCl}$ to $250 \mathrm{ml}$ at a wavelength of $660 \mathrm{~nm}$. Furthermore, after the OD of each isolate has been adjusted then $750 \mathrm{ml}$ of beer wastewater was added. Whereas the other tub only added as much as $1 \mathrm{~L}$ of beer wastewater as a control. Each tub was aerated by using aerators and analyzed with different days.
After the measurement of the pollutant parameters of the capabilities of each bacterial isolates, so that the best individual isolates will be obtained, which are capable to reduce the organic content concentration. Each water sample was analyzed for five pollutant parameters such as BOD (biochemical oxygen demand), COD (chemical oxygen demand), TSS (total suspended solid), temperature, and $\mathrm{pH}$ by standard methods prescribed by APHA, AWWA, WEF (1998) and Bridgewater et al., 2008. Then the isolates showed the best ability to degrade the beer wastewater were chosen to compose a combination of microbial consortium and tested again to lower the beer wastewater based on pollutant parameters.

\section{Identification of bacteria}

The identification of bacteria using the kit of MicrogenTM GN-ID A + B panel was done by taking bacterial isolates that have been incubated in NA media for 24 hours as much as 7 loop, dissolved in $10 \mathrm{~mL}$ of sterile $0.85 \% \mathrm{NaCl}$ solution and $20 \mu \mathrm{L}$ was pipetted into each well of Microgen panel kit, and then mineral oil was added into the particular panel well and was incubated for 24 hours. After 24 hours, $20 \mu \mathrm{L}$ reagent was added into certain panels well. The test results reading was conducted by comparing the color changes in each well to the color chart test panels available (Hadioetomo, 1993).

\section{RESULTS AND DISCUSSION}

\section{Isolation of bacteria and bacterial growth phase}

Bacteria isolated from soil contaminated by beer wastewater using serial dilution method were obtained 11 isolates of bacteria with different morphological characteristics which include shape, color, edge and size of colonies as shown in Table 1.

Generally, microbes will be able to live if the nutrients in the place or location of the microbe lives fulfilled. The bacteria can utilize organic materials contained in the beer wastewater as required nutrients to grow and produce biomass (Bitton, 2005). The increase of the concentration of microbial biomass is closely related to the provision of adequate nutrition for growth and environmental conditions are suitable to support the growth and activities of microbes to break down organic 
materials to be dissolved in a relatively short time (Bitton, 2005; Sumarsih, 2003 ).

The study results of the phase of cell growth to an average of 11 bacterial isolates was found that on the second observation day, the exponential phase had been seen as shown in Fig. 1.

Measurement of cell mass can be done by measuring the culture turbidity using a spectrophotometer. The exponential phase achieved within two days in the study. According to Hidayat et al., (2006) the exponential phase shows that microbial enzyme systems already adapt to utilize the media component for growth. After the acclimatization process, the enzyme system will be in accordance with existing components in the substrate, so that the power of microorganisms to degrade will increase.

\section{Degradation activity test of microbial consortium}

Determination to form bacterial consortium was conducted with capability test from 11 individual bacterial isolates. The capability test results demonstrate that three bacterial isolates capable of degrading wastewater, compared to other isolates based on pollutant parameters BOD, COD and TSS. All three of these bacteria are isolates with the code NGS4, NGS5 and NGS7.

Reduction of COD concentration by isolates NGS4, NGS5 and NGS7 at a certain time were 2224.26 \pm 853.9 ; 1724.28 \pm 864.8 ; and 2367.45 \pm 604 respectively. Reduction of $B O D$ concentration by isolates NGS4, NGS5 and NGS7 at a certain time were $317.11 \pm 25.1 ; 302.89 \pm 29.4$; and $350.68 \pm 9.4$ respectively. Reduction of TSS concentration by isolates NGS4, NGS5 and NGS7 at a certain time were $2493.25 \pm 274.5 ; 1722.50 \pm 167.9$ and $2660.5 \pm 421.7$ respectively. The results of the study

Table 1: Morphological characteristic of bacterial colony

\begin{tabular}{|c|c|c|c|c|c|}
\hline No. & $\begin{array}{l}\text { Isolates } \\
\text { Code }\end{array}$ & Characteristics & Gram & Cell Shape & Description \\
\hline 1. & NGS1 & $\begin{array}{l}\text { Circular colonies, orange yellow, } \\
\text { the edges undulate, non-motile }\end{array}$ & + & Coccus & $\begin{array}{l}\text { Form Colony } \\
\text { Circular }\end{array}$ \\
\hline 2. & NGS2 & $\begin{array}{l}\text { Irregular colonies, white, } \\
\text { edges entire, non-motile }\end{array}$ & + & Basil & Irregular \\
\hline 3. & NGS3 & $\begin{array}{l}\text { Irregular colonies, yellow, } \\
\text { edges undulate, non-motile }\end{array}$ & - & Coccus & $\begin{array}{l}\text { Edge of } \\
\text { The Colony }\end{array}$ \\
\hline 4. & NGS4 & $\begin{array}{l}\text { Irregular colonies, reddish white, } \\
\text { the edges undulate, non-motile }\end{array}$ & - & Basil & Filamentous \\
\hline 5. & NGS5 & $\begin{array}{l}\text { Irregular colonies, transparent white, } \\
\text { the edges undulate, non-motile }\end{array}$ & - & Basil & $\begin{array}{c}\text { Entire } \\
\text { Undulate }\end{array}$ \\
\hline 6. & NGS6 & $\begin{array}{l}\text { Irregular colonies, yellow, } \\
\text { edges undulate, non-motile }\end{array}$ & + & Coccus & Cell Shape \\
\hline 7. & NGS7 & $\begin{array}{l}\text { Circular colonies, transparent } \\
\text { green, entire edge, non-motile }\end{array}$ & - & Basil & Coccus Basil \\
\hline 8. & NGS8 & $\begin{array}{l}\text { Circular colonies, white cotton, } \\
\text { filamentous edge, non-motile }\end{array}$ & + & Basil & \\
\hline 9 & NGS9 & $\begin{array}{l}\text { Irregular colonies, white, } \\
\text { edges undulate, non-motile }\end{array}$ & + & Basil & \\
\hline 10 & NGS10 & $\begin{array}{l}\text { circular Colonies, white, } \\
\text { edges entire, non-motile }\end{array}$ & + & Basil & \\
\hline 11 & NGS11 & $\begin{array}{l}\text { Circular colonies, transparent white, } \\
\text { the edges entire, non-motile }\end{array}$ & + & Basil & \\
\hline
\end{tabular}




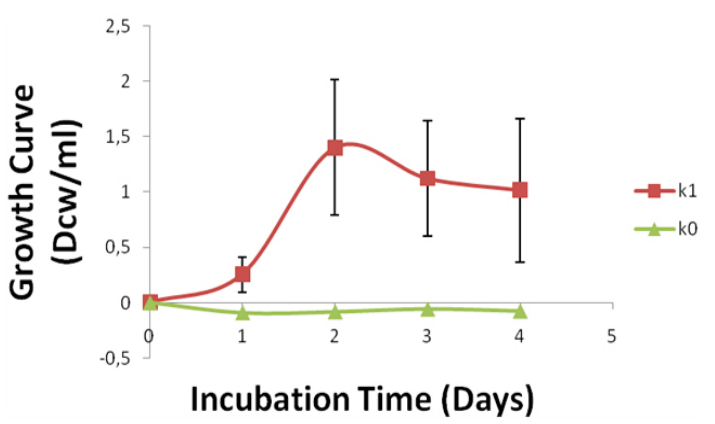

Fig. 1: The mean growth curve of 11 bacterial isolates were measured by a spectrophotometer. $\mathrm{K} 1$ is the average growth patterns of 11 isolates of bacteria and $K 0$ is the control (medium without microbial isolates) to the $\mathrm{pH}$ value by isolates NGS4, NGS5 and NGS7 at a certain time were $6.51 \pm 0.4 ; 6.59 \pm 0.4$ and $5.98 \pm 0.6$ respectively. The results of the study to the temperature value by isolates NGS4, NGS5 and NGS7 at a certain time were $26.97 \pm 0.8 ; 27.82 \pm 1.1$ and $26.74 \pm 1.2$ respectively for all data are presented in Fig. 2.

According to the Hidayah and Shovitri (2012), microbes will be able to live based on the ability to compete with other microbes in competing for nutrients and based on the type of nutrients present in the medium, so if the environment and nutrition in accordance with the origin of the microbes, they will adapt faster. Microbes able to adapt more quickly will improve their ability to break down organic materials contained in the waste. According to the Komarawidjaja (2007), temperature
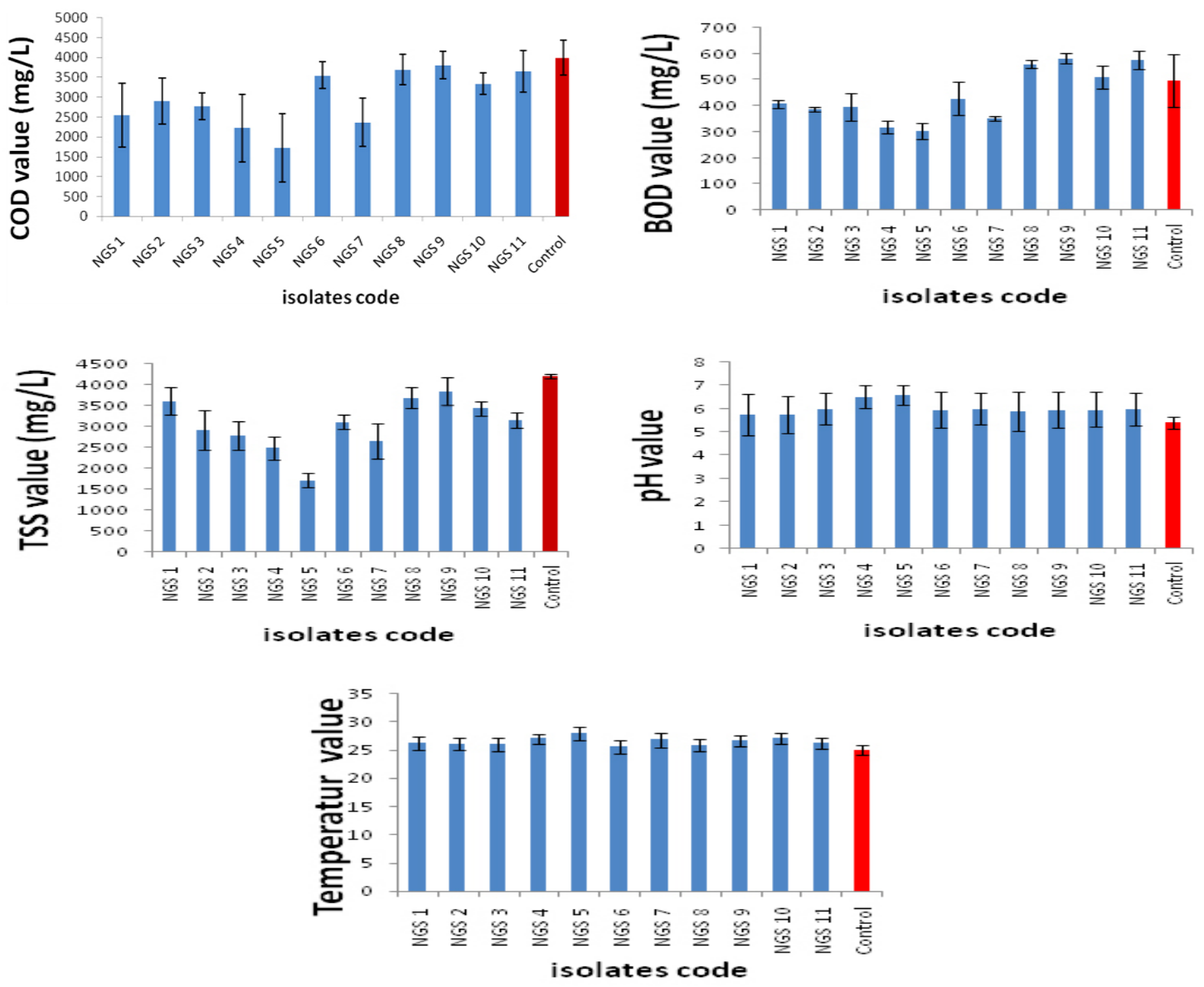

Fig. 2: Value change of COD, BOD, TSS, pH and temperature by using 11 isolates bacteria in degradating beer wastewater for 12 days treatment 
and $\mathrm{pH}$ are environmental factors that influence the microbial population increase and the ability of microbes in decomposition of organic matter.

The results of microscopic observation of the three colonies of bacteria are bacteria Gram-negative and has the form of basil cells (Fig. 3). All isolates had the ability to grow at an optimum temperature of $35-37^{\circ} \mathrm{C}$. The results of the study of bacterial species identification is using MicrogenTM kit GN-ID A + B panet, and the results are: Cronobacter sp. strain NGS4, Pseudomonas fluorescent NGS5, and Aeromonas sp. strain NGS7 (Fig. 4).

The three of selected bacterial isolates were then retested their ability to degradated beer wastewater in combination of isolates or mixed combination to determine the synergism between them, namely isolates NGS4, NGS5 and NGS7. Combination 1 is a combination of isolates NGS4 and NGS5, Combination 2 is a combination of isolates NGS4 and NGS7 and Combination 3 is a combination of isolates NGS5 and NGS7. The combination of a mixture is a combination of all three isolates NGS4, NGS5 and NGS7.
The ability of isolate combination and mixed combination in lowering the COD value indicates that the average of combination 1 , combination 2 , combination 3 , mixed combination and control are $882.64 \pm 28.15 \mathrm{mg} / \mathrm{L}, 859.981 \pm 15.62 \mathrm{mg} / \mathrm{L}$, $868.384 \pm 29.10 \mathrm{mg} / \mathrm{L}, 633.69 \pm 48.18 \mathrm{mg} / \mathrm{L}$ and $886.216 \pm 19.69 \mathrm{mg} / \mathrm{L}$ respectively. BOD values with microbial consortium combination after processing showed an average of combination 1, combination 2, combination 3 , mixed combination and control were $294.174 \pm 7.12 \mathrm{mg} / \mathrm{L}, 280.61 \pm 13.46 \mathrm{mg} / \mathrm{L}, 319.246$ $\pm 12.71 \mathrm{mg} / \mathrm{L}, 199.09 \pm 87.82 \mathrm{mg} / \mathrm{L}$ and $312.646 \pm$ $2.26 \mathrm{mg} / \mathrm{L}$ respectively (Fig. 5).

The results showed a decline in the value of COD and BOD in beer wastewater treatment. COD value will decrease due to oxidation of organic matter, but it is higher than the BOD because the production of some substance that is difficult to degrade.

The reductions of $C O D$ and $B O D$ concentrations be affected by activities microorganisms that can break down the organic compounds either suspended or dissolved in the beer wastewater. The reduction of BOD and COD could
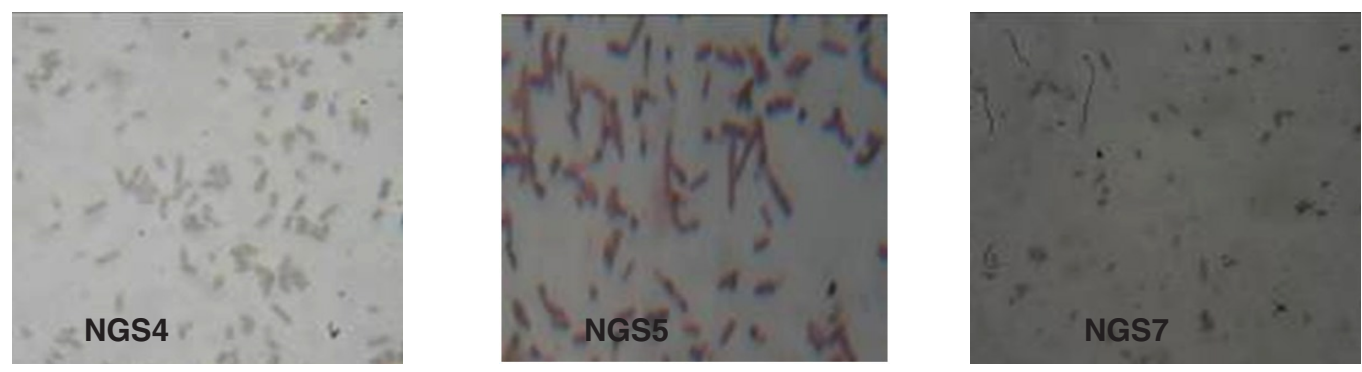

Fig. 3: Results of Gram staining isolates Cronobacter sp. strain NGS4, Pseudomonas fluorescent NGS5, and Aeromonas sp. strain NGS7.
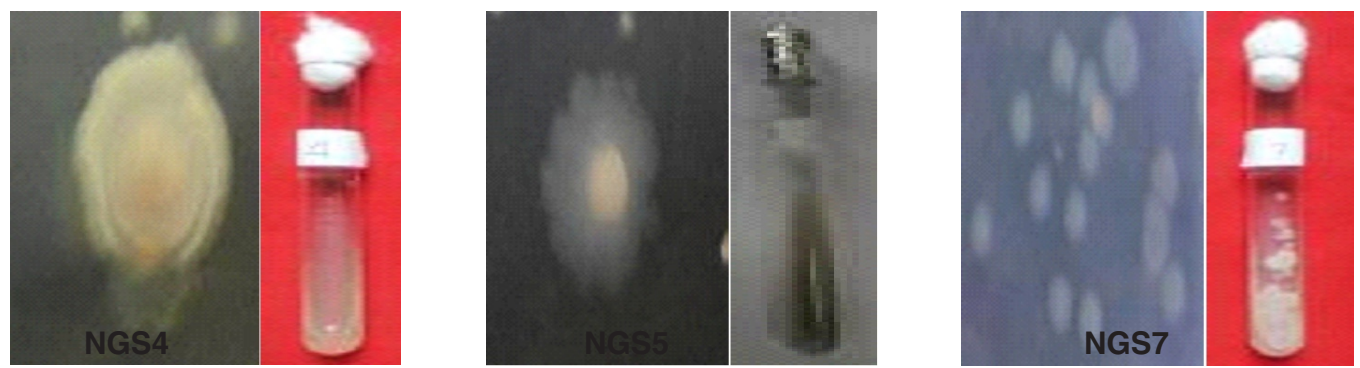

Fig. 4: Cronobacter sp. strain NGS4, Pseudomonas fluorescent NGS5, and Aeromonas sp. strain NGS7 
be caused by oxidation of organic matter in system that provides energy for microbial metabolism. The organic matter contained in the wastewater provides a substrate for aerobic microbial metabolism and the length of culturization time could lead to a decrease of $C O D$ and $B O D$ concentration. In addition, the reduction of $B O D$ and $C O D$ were also influenced by the length of aeration time (Metcalf and Eddy, 2003; Suhendrayatna et al., 2012).

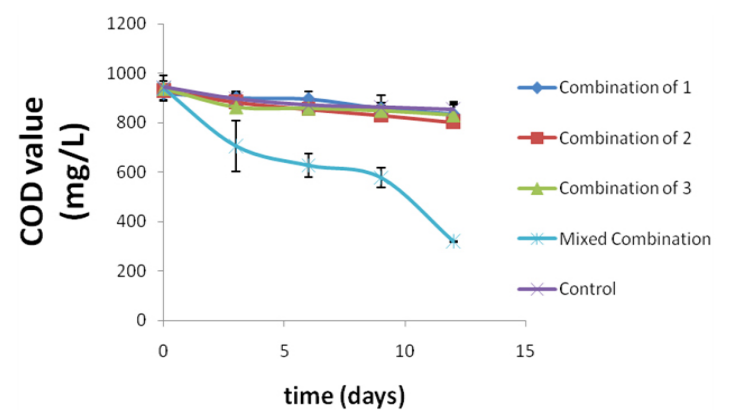

The results showed a decline in the value of the TSS of each combination of microbial consortium after processing namely combination 1 , combination 2 , combination 3 , mixed combination and control were $2160 \pm 87.68 \mathrm{mg} / \mathrm{L}, 2531 \pm 64.77 \mathrm{mg} / \mathrm{L}, 2139$ $\pm 38.75 \mathrm{mg} / \mathrm{L}, 848.9 \pm 206.61 \mathrm{mg} / \mathrm{L}$ and $189.78 \pm$ $3744 \mathrm{mg} / \mathrm{L}$ respectively (Fig. 6).

TSS is the amount of suspended solids in waste water is filtered by membrane filters, the

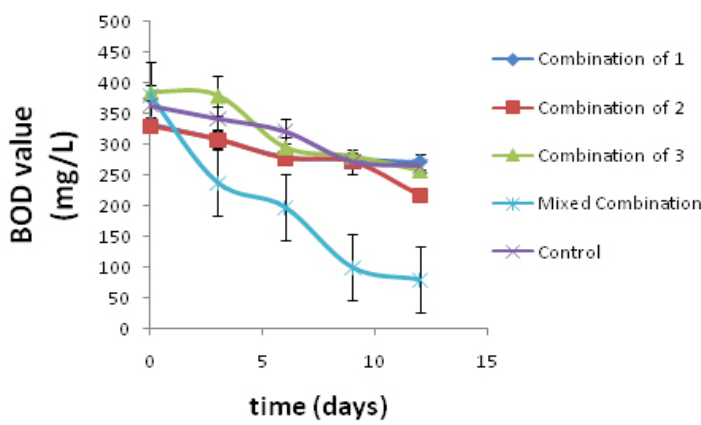

Fig. 5: Degradation rate of COD and BOD value by the isolates combination and the mixed combination in degradating beer wastewater for 12 days treatment

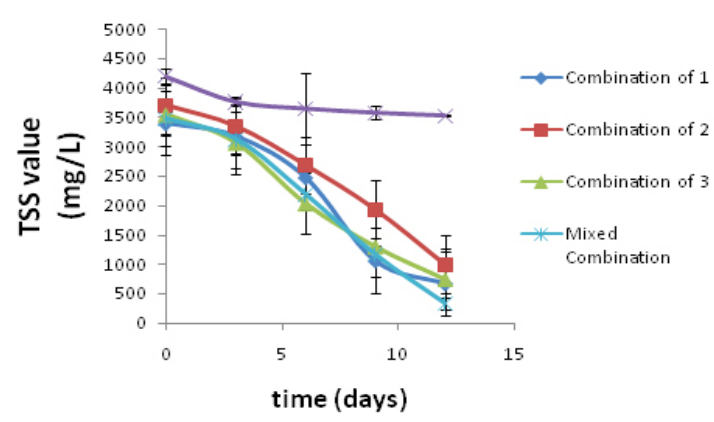

Fig. 6: Degradation rate of TSS value by the isolates combination and the mixed combination in degradating beer wastewater for 12 days treatment

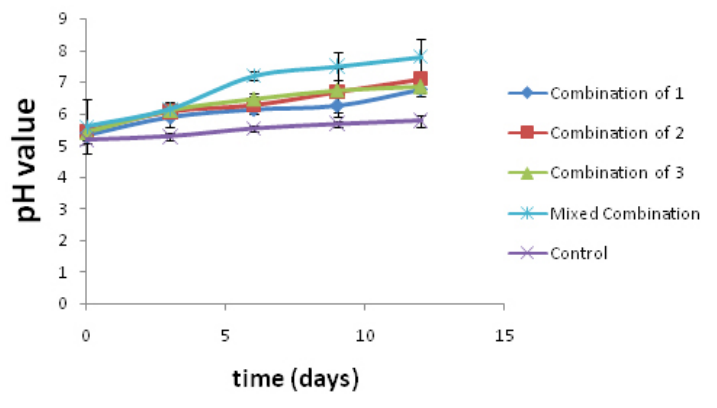

smaller the reduction in TSS values show that the smaller the waste biodegradation processes that occur (Wirda and Handajani, 2011). Decrease of TSS value due to particle deposition factors and organic matter decomposition processes from suspended particles become dissolved by microbial.

Organic compounds in the waste is degraded by bacteria by secreting enzymes to hydrolyze complex organic compounds (starch, protein, and fat) into simpler compounds that in the first phase, the complex compounds are converted into simple compounds such as sugars, glycerol, fatty acids and amino acids. The simple compounds

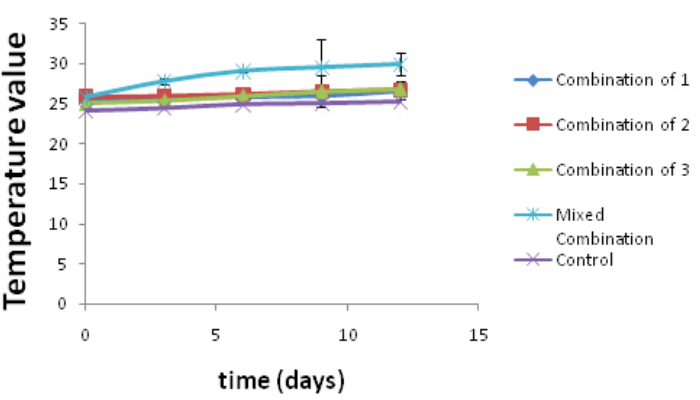

Fig. 7: Degradation rate of TSS value by the isolates combination and the mixed combination in degradating beer wastewater for 12 days treatment 
are used for the metabolism of bacteria which will then be followed by other processes, both aerobic and anaerobic energy thus produced, $\mathrm{CO}_{2}, \mathrm{H}_{2} \mathrm{O}$ and metabolic wastes in the form of a simple mud settles, so that with this mechanisms organic contaminant material presents in the waste will be reduced (Radojevic and Vladimir, 1999). In addition, the aeration serves as a supplier of oxygen so that the microbes can grow and multiply in the presence of oxygen in the water, so it is enough to absorb and digest the organic impurities (Arixs, 2009).

The results of the study to demonstrate the value of the average $\mathrm{pH}$ in combination 1 , combination 2 , combination 3 , mixture combination and control are $6.07 \pm 0.5,6.30 \pm 0.6,6.31 \pm 0.5$, $6.85 \pm 0.9$ and $5.48 \pm 0.2$ respectively. While the value of the temperature shows average of the combination 1, combination 2, combination 3, mixture combination and control are $25.84 \pm 0.4$, $26.26 \pm 0.3,25.9 \pm$ of $0.7,28.39 \pm 1.6$ and $24.72 \pm$ 0.4 respectively (Fig. 7 ).

Hydrogen ion concentration $(\mathrm{pH})$ indicates the intensity of acidic or basic character at a given temperature. Measurement of $\mathrm{pH}$ is one of the most important and most frequently used tests in determining water quality (Choudhary et al., 2011). Changes of $\mathrm{pH}$ in wastewater suggests that there has been activity of microorganisms that degrade organic matter. Degradation of proteins and organic nitrogen into ammonium $\left(\mathrm{NH}_{4}\right)$ raises the $\mathrm{pH}$ and becomes alkaline. Increasing of the $\mathrm{pH}$ occurs on the hydrolysis process which when $\mathrm{H}^{+}$is used to catalyze the bond termination on polysaccharides, lipids and proteins (Paramita et al., 2012).

Temperature is one of the most important factors in aquatic environment. Temperature also affects solubility of oxygen in water (Singh et al., 2005). The increase in temperature in the wastewater can accelerate the degradation rate of the organic compounds, microbial growth rate (total number of microbial growth, rate of enzyme synthesis and enzyme inactivation rate) and a decrease in gas solubility in water such as $\mathrm{O}_{2}, \mathrm{CO}_{2}, \mathrm{~N}_{2}$ and $\mathrm{CH}_{4}$. In addition, the increase in temperature in the wastewater can be caused by aeration (Haslam, 1995)
The results show, that synergism between the isolates combination and the mixture combination showed different abilities. The mixture combination is more effective than in the form of single bacterial culture and combination of multiple isolates in degrading organic matter content of beer wastewater. According to Cahyonugroho and Hidayah, (2008) and Jadhav et al., (2008) wastewater is a complex mixture of a compound, while each type of bacteria has limited ability in degrading it. Bacterial consortium can be used as a starter which is potential for wastewater recovery. Therefore, the presence of the catabolic activity of the bacterial culture complement each other and the resulting decomposition products of a culture can be used by other cultures for further decomposition process, so that it can help improve wastewater oxidation of organic matter.

Diversity can improve the stability of the community due to the presence of more diverse species and results that the community is being able to adapt to varied environmental conditions (Worm and Duffy, 2003). In addition, bacteria from different genera can work together in an environment and survive through the metabolites interaction because a mixed culture has a more complete overhaul capabilities and have a higher tolerance to toxic metabolites (De Souza et al., 1998; Mlynarz and Ward, 1995).

\section{CONCLUSION}

The most effective microbial consortia combination capable of lowering the value of pollutant parameter is a mixed combination (Cronobacter sp. strain NGS4, Pseudomonas fluorescent NGS5, and Aeromonas sp. strain NGS7) after the treatment for 12 days namely COD, BOD, TSS are $633.69 \pm 48.18$ $\mathrm{mg} / \mathrm{L}$ with a degradation rate of $66,06 \%, 199.09 \pm$ $87.82 \mathrm{mg} / \mathrm{L}$ with a degradation rate of $78.91 \%$ and $848.9 \pm 206.61 \mathrm{mg} / \mathrm{L}$ with a degradation rate of $90.50 \%$ respectively.

\section{ACKNOWLEDGEMENTS}

The authors thanks to PT. Storm Beer for providing samples for the research and wastewater treatment plant (PT. IPAL) Suwung-Bali for the assistant in beer wastewater analysis. 


\section{REFERENCES}

1. Olafadehan, O. A dan Aribike, D. S., Treatment of Industrial Wastewater Effluent: Adsorption of Organic Compounds on Granular Activated Carbon, J. Nig. Soc. Chem. Eng, 19 (1,2): $50-$ 57 (2000).

2. Driessen, W., dan Vereijken, T., Recent Developments in Biological Treatment of Brewery Effluent, The Institute and Guild of Brewing Convention, Zambia (2003).

3. Bitton, G., Wastewater Microbiology, Third Edition, John Wiley and Sons Inc, New Jersey (2005).

4. Nusantary, DL, Colby, ER, and Santosa, H., Domestic Wastewater Treatment in Biological Media Active Sludge, Journal of Chemical Technology and Industry, 1 (1): :454-460 (2012) (Indonesian).

5. Thompson, I. P., van der Gast, C. J., Ciric, L. and Singer, A. C., Bioaugmentation for Bioremediation: The Challenge of Strain Selection, Environmental Microbiology, 7 (7): 909-915 (2005).

6. Jadhav, S. U., Jadhav, U. U., Dawkar, V.V., dan Govindwar, S. P., Biodegradation of Disperse Dye Brown 3REL by Microbial Consortium of Galactomyces Geotrichum TCC 1360 and Bacillus sp. VUS, Biotechnology and Bioprocess Engineering, 13: 232-239 (2008).

7. Kardono, Environmental Laboratory Requirements and Conditions in Indonesia, Journal of Environmental Engineering, 9 (2): 109-120 (2008) (Indonesian).

8. Khehra, M. S., dan Chimni, S. S., Biodegradation of Azo Dye C. I. Acid Red 88 by An Anoxic-Anaerobic Sequential Bioreactor, Dyes and Pigments, 70: 1-7 (2006).

9. Waluyo, Lud., General Microbiology, University Press of Muhammadiyah, Malang (2004) (Indonesian).

10. APHA, AWWA, WEF, Standard methods for the examination of water and waste water (20th edn.), Washington, DC: American Public Health Association (1998).

11. Bridgewater, A., Conner, B., and Slezycki, M., Minimization of Environmental Impact of Wachusett Brewing Company Processes (Undergraduate Thesis), Bachelor of Science
Degree in the field of Chemical Engineering Faculty of the Worcester Polytechnic Institute, Worcester (2008).

12. Hadioetomo, R. S., Basic Microbiology in Practice: Basic Laboratory Techniques and Procedures, PT Gramedia Pustaka Utama, Jakarta (1993) (Indoensian).

13. Sumarsih, S., Basic Microbiology, Department of Soil Science, Faculty of Agriculture, UPN, Yogyakarta (2003) (Indonesian).

14. Hidayat, N., M.C Padaga, and S. Suhartini., Industrial Microbiology, ANDI, Yogyakarta (2006) (Indoensian).

15. Hidayah, N., and Shovitri, M, Adaptation of Aerobic Bacterial Isolates Producer Hydrogen Gas in Medium Organic Waste, Journal of Science and Arts ITS, 1:16-18 (2012) (Indonesian).

16. Komarawidjaja, W., Aerobic Microbial Role in Textile Wastewater Treatment, Journal of Environmental Engineering, 8 (3): 223-228 (2007) (Indonesian).

17. Metcalf dan Eddy. 2003. Wastewater Engineering: Treatment, Disposal and Reuse, $4^{\text {th }}$ ed., Mc Graw Hill Book Co, New York (2003).

18. Suhendrayatna, Marwan, Andriani, R., Fajriana, Y., and Elvitriana, Removal of Municipal Wastewater BOD, COD and TSS by Phyto-Reduction: A Laboratory-Scale Comparison of Aquatic Plants at Different Species Typha Latifolia and Saccharum Spontaneum, International Journal of Engineering and Innovative Technology (IJEIT), 2(6):333-337 (2012).

19. Wirda, F. R., and Handajani, H., Degradation of Organik Compound in Liquid Phase Biowaste with Additional Water Variation at Ratio 1:2 in Batch Reactor, Institute of Technology Bandung, Bandung (2011) (Indonesian).

20. Radojevics, M. and B. N. Vladimir., Practical Environmental Analysis, The Royal Society of Chemistry, Chambridge (1999).

21. Arixs, Extended Aeration System More Effective and Efficient Wastewater Treat, http:URL:File://H:/Bahan\%/ 1\% 202009/mod. php.htm Cited: 05 Dec 2013

22. Choudhary, R., Rawtani, P., and Vishwakarma, 
M., Comparative study of Drinking Water Quality Parameters of three Manmade Reservoirs i.e. Kolar, Kaliasote and Kerwa Dam, Journal of Current World Environment, 6(1):145-149 (2011)

23. Paramita, P., Shovitri, M., and Kuswytasari, N. D., Biodegradation of Organic Waste Market by Microorganism Natural Septic Tank, Journal of Science and Arts ITS, 1 (1) :23-26 (2012) (Indonesian).

24. Singh, R.P.and Mathur, P., Investigation of Variations in Physico Chemical Characteristics of Fresh Water Reservoir of Ajmer city, Rajasthan, Ind. J. Env., 9: 57-61 (2005).

25. Haslam, S.M., River Pollution, an Ecological Perspective, Belhaven Press, London UK (1995).

26. Cahyo Nugroho, O. H, and Hidayah, E., Allowance Metal Chrome Using
Microorganism Consortium, Journal of Environmental Engineering, 1 (1): 20-29 (2008) (Indonesian).

27. Worm, B., dan Duffy, J. E., Biodiversity, Trends in Ecology and Evolution, 18: 628"632 (2003).

28. De Souza, M.L., Newcombe, D., Alvey, S., Crowley, D.E., Hay, A., Sadowsky, M.J., dan Wackett, L.P., Molecular Basis of a Bacterial Consortium: Interspecies Catabolism of Atrazine, Appl Environ. Microbiol, 64: 178-184 (1998).

29. Mlynarz, T. D ., dan Ward, O. P., Degradation of Polycyclic Aromatic-Hydrocarbons (PAHs) by a Mixed Culture and its Component Pure Cultures, Obtained from PAH-Contaminated Soil, J. Microb., 41: 470"476 (1995). 